\title{
Penerapan Model Pembelajaran STAD Kuis Kompetisi Kelompok untuk Meningkatkan Minat Belajar PKn
}

\author{
REGENG \\ Guru PKn SMK N 1 Pandak, Bantul, Daerah Istimewa Yogyakarta \\ regengmangir@gmail.com
}

\begin{abstract}
Abstrak
Penelitian ini bertujuan memperbaiki proses pembelajaran melalui model pembelajaran kooperatif STAD kuis kompetisi kelompok untuk meningkatkan minat belajar PKn pada siswa kelas X Agribisnis Ternak Unggas (ATU) 2 di SMK Negeri 1 Pandak Menggunakan penelitian tindakan kelas (Classroom Action Reasearch). Dilaksanakan dalam dua siklus Pengumpulan data dilakukan melalui observasi langsung saat pembelajaran. Indikator keberhasilan didasarkan pada rerata persentase peningkatan minat dari 25\% menjadi 75\%. Data dianalisis dengan statistika deskriptif kuantitatif dengan persentase. Hasil penelitian menunjukkan bahwa penerapan model pembelajaran STAD kuis kompetisi kelompok dapat meningkatkan minat belajar siswa. Hal ini dilihat dari peningkatan rerata persentase minat siswa dalam pembelajaran PKn.
\end{abstract}

Kata kunci : STAD kuis kompetensi kelompok, minat belajar, PKn

\begin{abstract}
The study explains about the recover of learning process with STAD Quiz Group Competitin Learning Model to increase the interest of study for Civil Education in the students of Agribusiness-Livestock-Fowl Class 2, Pandak Senior High School. It used Classroom Action Reasearch and was displayed for two cycles. Collecting data used direct observation that showed in the class. The successful indicates were based on the average of percentage of interest from $25 \%$ to $75 \%$. The analysis use descriptive statistic. The results show that the implementation of STAD Quiz Group Competition Learning Models increase the interest to study Civil Education. It was noted by the rate of increasing percentage to study in the subject.
\end{abstract}

Keywords: STAD Quiz Group Competition, the interest of study, Civil Education 


\section{PENDAHULUAN}

Kewarganegaraan dan kepribadian merupakan kelompok mata pelajaran yang dimaksudkan untuk meningkatkan kesadaran dan wawasan peserta didik akan status, hak, dan kewajibannya dalam kehidupan bermasyarakat, berbangsa, dan bernegara serta meningkatkan kualitas dirinya sebagai manusia (Permendiknas RI No.22 tahun 2006). Dalam struktur kurikulum pendidikan kejuruan bertujuan untuk meningkatkan kecerdasan, pengetahuan, kepribadian, akhlak mulia serta keterampilan peserta didik untuk hidup mandiri dan mengikuti pendidikan lebih lanjut sesuai dengan program kejuruannya. Untuk mencapai tujuan tersebut kurikulum SMK berisi mata pelajaran wajib, mata pelajaran kejuruan, muatan lokal, dan pengembangan diri. Mata pelajaran wajib bertujuan untuk membentuk manusia Indonesia seutuhnya dalam spektrum manusia kerja (Permendiknas RI No.22 th 2006).

Mata Pelajaran Pendidikan Kewarganegaraan (PKn) yang merupakan salah satu dari pelajaran wajib diharapkan dapat memberikan kontribusi untuk mencapai tujuan tersebut dan mendapat perhatian yang sama dengan mata pelajaran yang lain, namun yang terjadi tidaklah demikian. PKn dianggap tidak penting, hanya pelengkap dari mata pelajaran kejuruan dan mata pelajaran yang di- UN- kan lainnya.

Kenyataan yang terjadi pada siswa kelas X Agribisnis Ternak Unggas (ATU) 2 di SMK Negeri 1 Pandak kurang mendukung untuk mencapai tujuan tersebut di atas karena kedisiplinan siswa rendah. Hal tersebut tampak dari seringnya siswa terlambat masuk kelas baik ketika mulai jam pertama maupun setelah istirahat. Minat belajar siswa rendah, kalau diberi tugas sering tidak dikerjakan, sehingga hasil belajar pun rendah (di bawah KKM).

Pembelajaran PKn selama ini banyak menggunakan metode ceramah bervariasi, diskusi, dan penugasan. Pada pembelajaran berlangsung banyak siswa yang kurang fokus terhadap materi pelajaran, ketika kegiatan diskusi banyak siswa yang tidak aktif melaksanakan diskusi, tugas-tugas yang diberikan guru tidak terselesaikan dengan baik bahkan banyak yang tidak mengerjakan sama sekali.

Mengingat kenyataan di atas diperlukan strategi yang mampu menciptakan suasana pembelajaran yang menarik dan dapat memotivasi siswa untuk meningkatkan minat belajar siswa agar hasil belajar meningkat, dan akhirnya tujuan pembejaran tercapai sesuai harapan. Berkaitan dengan hal tersebut di 
atas diperlukan model/ metode menarik maka diperlukan strategi/model pembelajaran yang dapat mengatasi pembelajaran yang lebih menarik dan berbagai problematika dalam pelaksanaan dapat meningkatkan minat dan hasil pembelajaran. Syaiful Sagala (2004: 176) belajar sehingga tujuan tercapai. Dalam mengatakan bahwa model pembelajaran hal ini yang sesuai dengan karakteristik dirancang untuk mewakili realitas yang siswa salah satu upaya yang dapat sesungguhnya, walaupun model itu sendiri dilakukan adalah dengan memilih model bukanlah realitas dari dunia yang pembelajaran kooperatif Student Teamsebenarnya. Atas dasar pengertian Achiement Division (STAD). Dalam STAD, tersebut, maka model mengajar dapat para siswa dibagi dalam tim belajar yang difahami sebagai kerangka konseptual terdiri atas empat orang yang berbedayang mendeskripsikan dan melukiskan beda tingkat kemampuan, jenis kelamin, prosedur yang sistematik dalam dan latar belakang etniknya. Guru mengorganisasikan pengalaman belajar menyampaikan pelajaran, lalu siswa dan pembelajaran untuk mencapai tujuan bekerja dalam team mereka untuk belajar tertentu, dan fungsi sebagai memastikan bahwa semua anggota team pedoman bagi perencanaan pengajaran telah menguasai pelajaran. Selanjutnya, bagi para guru dalam pelaksanaan semua siswa mengerjakan kuis mengenai aktivitas. Sobry Sutikno (2007) menjelaskan bahwa dalam proses pembelajaran seorang pendidik dituntut untuk dapat membangkitkan motivasi belajar pada diri peserta didik. Selanjutnya dijelaskan oleh Budiono (1998) bahwa salah satu usaha yang dapat dilakukan untuk meningkatkan motivasi belajar peserta didik adalah guru mampu menerapkan model pembelajaran yang inovatif sehingga peserta didik menikmati kegiatan belajar.

Sejalan dengan pengalaman, materi secara sendiri-sendiri, dimana saat itu mereka tidak dibolehkan untuk saling bantu (Robert E.Slavin, 2009: 11).

Dengan model pembelajaran kooperatif STAD kuis diharapkan dapat memberikan solusi terhadap permasalahan dalam pembelajaran PKn di kelas X ATU 2 dengan alasan pembelajaran kooperatif tipe STAD kuis tersebut dapat menanamkan sikap dalam diri siswa seperti saling menghargai, membantu, sabar, menghormati, dan bertanggung jawab. Dalam pembelajaran tersebut siswa kenyataan, dan uraian di atas agar akan mempunyai kebebasan untuk pembelajaran PKn di kelas X ATU 2 bertindak, berdiskusi, dan saling memberi 
informasi untuk memahami suatu konsep dalam PKn. Siswa bekerja sama dalam kelompok untuk memecahkan masalah. Pada akhirnya termotivasi untuk dapat belajar lebih baik, minat belajar meningkat sehingga hasil belajar pun meningkat

Berdasarkan uraian dan kondisi tersebut di atas penelitian tentang Implementasi model pembelajaran kooperatif STAD kuis kompetisi kelompok menjadi sebuah bentuk tindakan yang dilakukan untuk meningkatkan minat belajar PKn pada siswa kelas X ATU 2 SMK Negeri 1 Pandak.

\section{METODE}

Merupakan penelitian tindakan kelas (Classroom Action Research) dengan variabel yang dijadikan fokus utama untuk menjawab permasalahan yang dihadapi. Variabel yang diteliti adalah variabel masalah yang terdiri atas input, proses pembelajaran, dan output. Prosedur dan langkah-langkah penelitian ini mengikuti prinsip dasar penelitian tindakan kelas (PTK) yang terdiri atas beberapa tahap, yaitu rencana tindakan (planning), pelaksanaan tindakan (acting), pengamatan (observing) dan refleksi (reflecting).

Sumber data yang digunakan adalah siswa, dokumen, dan proses pembelajaran dengan menerapkan teknik STAD kuis kompetisi kelompok dengan jenis data kualitatif meliputi dokumen, data hasil observasi yang selanjutnya dianalisis dengan analisis deskriptif.

\section{HASIL DAN PEMBAHASAN}

\section{Deskripsi Kondisi Awal}

Sebelum pelaksanaan penelitian, dilakukan pengamatan pendahuluan di kelas yang menjadi subyek dalam penelitian yaitu kelas X ATU 2 SMK N 1 Pandak. Pengamatan yang dilakukan difokuskan pada seluruh kegiatan proses pembelajaran PKn yang berlangsung di kelas khususnya terkait dengan minat siswa dalam pembejaran PKn.

Berdasarkan temuan peneliti sebagai berikut:

Tabel 1. Analisis data minat siswa terhadap PKn secara klasikal pada kondisi awal

\begin{tabular}{|c|c|c|c|c|c|c|c|}
\hline $\begin{array}{l}\mathrm{N} \\
\mathrm{O}\end{array}$ & Indikator & $\begin{array}{l}\text { Jml } \\
\text { siswa }\end{array}$ & $\begin{array}{l}\mathrm{Y} \\
\mathrm{a}\end{array}$ & $\%$ & $\begin{array}{r}\mathrm{Ti} \\
\mathrm{da} \\
\mathrm{k}\end{array}$ & $\%$ & $\begin{array}{c}\text { Indikator } \\
\text { Perlu } \\
\text { perhatian }\end{array}$ \\
\hline 1 & $\begin{array}{l}\text { Memusatkan } \\
\text { perhatian } \\
\text { terhadap } \\
\text { materi } \\
\text { pelajaran }\end{array}$ & 15 & 3 & 20 & 12 & 80 & Perlu \\
\hline 2 & $\begin{array}{l}\text { Mengerjakan } \\
\text { tugas }\end{array}$ & 15 & 4 & 27 & 11 & 73 & Perlu \\
\hline 3 & $\begin{array}{l}\text { Mencatat } \\
\text { materi } \\
\text { pelajaran }\end{array}$ & 15 & 5 & 33 & 10 & 67 & Perlu \\
\hline 4 & $\begin{array}{l}\text { Merespon } \\
\text { positif } \\
\text { terhadap } \\
\text { pelajaran } \\
\text { PKn } \\
\end{array}$ & 15 & 3 & 20 & 12 & 80 & Perlu \\
\hline & $\begin{array}{l}\text { Jumlah rata- } \\
\text { rata }\end{array}$ & & & 25 & & 75 & \\
\hline
\end{tabular}


Dari tabel di atas dapat disimpulkan bahwa hanya 25\% siswa yang berminat dalam pelajaran PKn, sementara yang kurang berminat masih $75 \%$ sehingga perlu dilakukan tindakan perbaikan dalam proses pembelajaran. Berdasarkan kondisi tersebut di atas yang didukung oleh dokumen yang berupa catatan guru sebelumnya dan pertimbangan berbagai kelebihan dan kelemahannya maka peneliti memutuskan untuk menggunakan model pembelajaran STAD. Berikut hasil penelitian yang telah dilakukan melalui observasi dalam pembelajaran PKn.

\section{Deskripsi Siklus I}

\section{Hasil Penelitian}

Dalam penelitian ini peneliti menyajikan materi pelajaran Sistem politik di Indonesia Pembelajaran dimulai dengan presentasi materi pelajaran, yang mencakup kegiatan awal (mengkondisikan kelas, apersepsi,motivasi, menyampaikan tujuan pembelajaran, pengembangan,dan pengarahan-pengarahan praktis tiap komponen dari keseluruhan proses pembelajaran ; kegiatan-kegiatan tim; kuis yang mencakup latihan dan penilaian individual). Selama proses pembelajaran berlangsung kolabolator melakukan observasi terhadap aktivitas siswa untuk memperoleh data tentang minat maupun partisipasi dalam pembelajaran.
Tabel 2.Proses pelaksanaan STAD Kuis Kompetisi Kelompok siklus I

\begin{tabular}{|c|c|c|c|c|}
\hline $\begin{array}{l}\mathrm{N} \\
\mathrm{o}\end{array}$ & Indikator & $\begin{array}{l}\text { Juml } \\
\text { Siswa }\end{array}$ & Frek & $\begin{array}{c}\text { Prosen } \\
\text { tase } \\
(\%)\end{array}$ \\
\hline \multirow[t]{6}{*}{1} & $\begin{array}{l}\text { Kemauan siswa untuk } \\
\text { mengerjakan LKS }\end{array}$ & \multirow{6}{*}{15} & & \\
\hline & $\begin{array}{ll}\text { a. } & \text { Siswa selalu } \\
& \text { mengerjakan LKS }\end{array}$ & & 4 & 26,67 \\
\hline & $\begin{array}{ll}\text { b. } & \text { Siswa sering } \\
& \text { mengerjakan LKS }\end{array}$ & & 5 & 33,33 \\
\hline & $\begin{array}{ll}\text { c. } & \text { Siswa jarang } \\
& \text { mengerjakan LKS }\end{array}$ & & 6 & 40 \\
\hline & $\begin{array}{ll}\text { d. } & \begin{array}{l}\text { Siswa tidak pernah } \\
\text { mengerjakan LKS }\end{array}\end{array}$ & & - & - \\
\hline & Total & & 15 & 100 \\
\hline
\end{tabular}

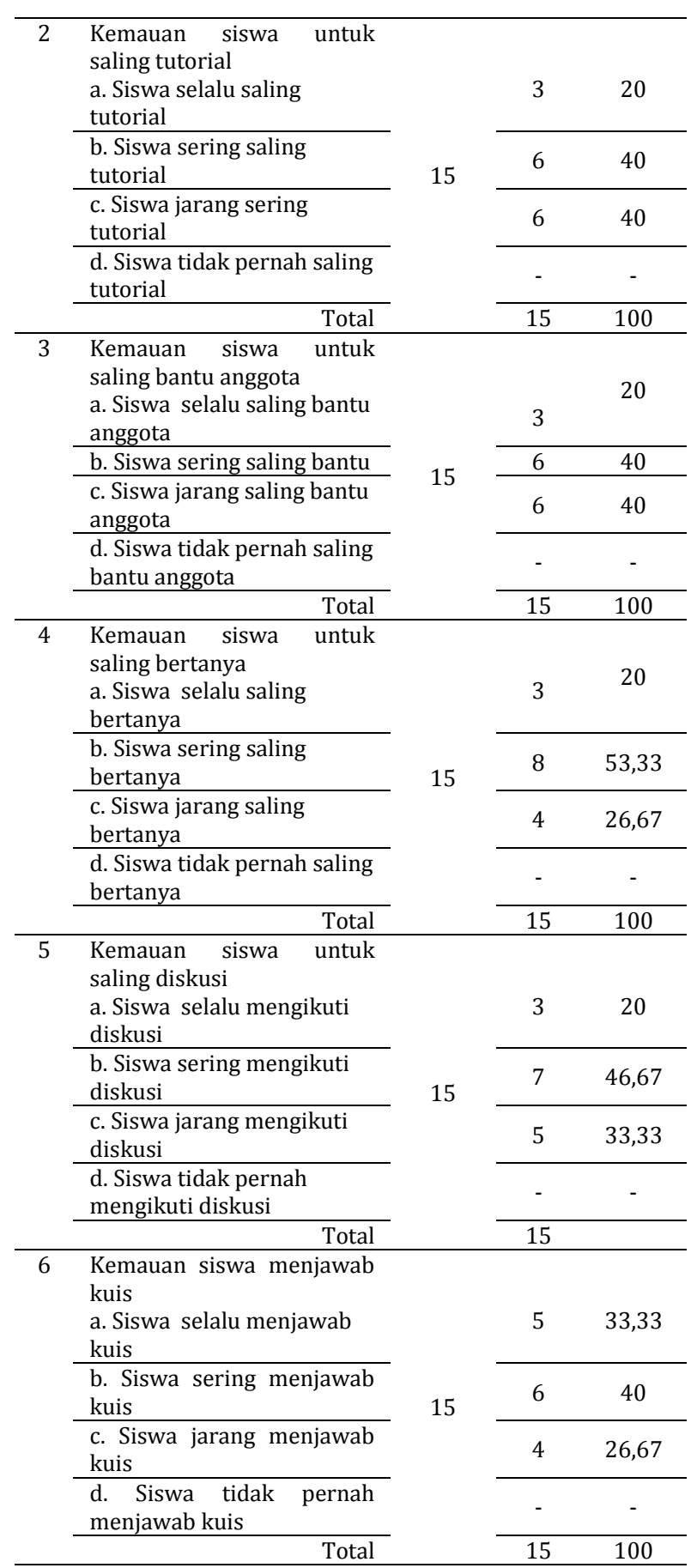


Tabel tersebut dapat menunjukkan bahwa model pembelajaran STAD mampu mengaktifkan siswa dalam pembelajaran PKn dengan turut berpartisipasi dalam seluruh proses kegiatan belajar.

Hasil pengamatan terhadap peningkatan minat siswa dalam pembelajaran PKn pada siklus I beserta analisisnya tercantum pada pada lampiran. Berdasarkan data tersebut dapat dilihat pada tabel berikut:

Tabel 3. Peningkatan minat siswa dalam pembelajaran PKn pada siklus I

\begin{tabular}{|c|c|c|c|c|c|c|c|}
\hline $\begin{array}{l}\mathrm{N} \\
\mathrm{o}\end{array}$ & Indikator & $\begin{array}{c}\text { Jml } \\
\text { sisw } \\
\text { a }\end{array}$ & $\begin{array}{l}\mathrm{Y} \\
\mathrm{a}\end{array}$ & $\%$ & $\begin{array}{c}\text { Tida } \\
\mathrm{k}\end{array}$ & $\%$ & $\begin{array}{c}\text { Indikato } \\
\text { r } \\
\text { Perlu } \\
\text { perhatia } \\
\text { n }\end{array}$ \\
\hline 1 & $\begin{array}{l}\text { Memusatka } \\
\mathrm{n} \text { perhatian } \\
\text { terhadap } \\
\text { materi } \\
\text { pelajaran }\end{array}$ & 15 & 9 & $\begin{array}{l}6 \\
0\end{array}$ & 6 & $\begin{array}{l}4 \\
0\end{array}$ & perlu \\
\hline 2 & $\begin{array}{l}\text { Mengerjaka } \\
\mathrm{n} \text { tugas }\end{array}$ & 15 & $\begin{array}{l}1 \\
0 \\
\end{array}$ & $\begin{array}{l}6 \\
7 \\
\end{array}$ & 5 & $\begin{array}{l}3 \\
3 \\
\end{array}$ & perlu \\
\hline 3 & $\begin{array}{l}\text { Mencatat } \\
\text { materi } \\
\text { pelajaran }\end{array}$ & 15 & $\begin{array}{l}1 \\
1\end{array}$ & $\begin{array}{l}7 \\
3\end{array}$ & 4 & $\begin{array}{l}2 \\
7\end{array}$ & perlu \\
\hline 4 & $\begin{array}{l}\text { Merespon } \\
\text { positif } \\
\text { terhadap } \\
\text { pelajaran } \\
\text { PKn }\end{array}$ & 15 & 9 & $\begin{array}{l}6 \\
0\end{array}$ & 6 & $\begin{array}{l}4 \\
0\end{array}$ & perlu \\
\hline & $\begin{array}{l}\text { Jumlah } \\
\text { rata-rata }\end{array}$ & & & $\begin{array}{l}6 \\
5 \\
\end{array}$ & & $\begin{array}{l}3 \\
5 \\
\end{array}$ & \\
\hline
\end{tabular}

Berdasarkan data tersebut minat siswa sudah ada peningkatan dari $25 \%$ menjadi $65 \%$
Diagram 1. Peningkatan minat siswa dalam pembelajaran PKn siklus I

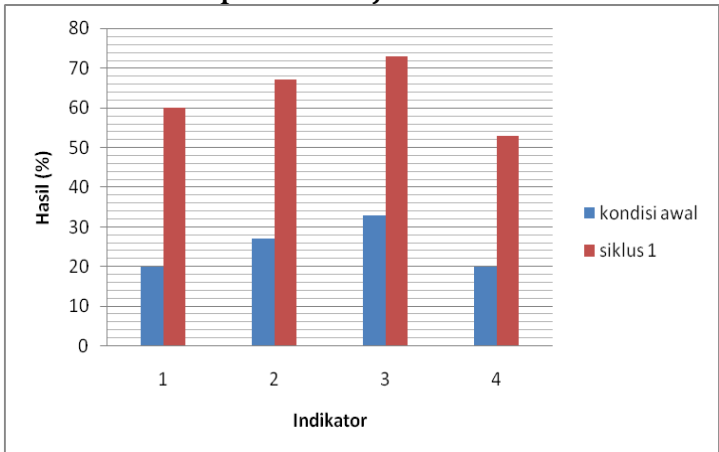

\section{Refleksi}

Dari pengolahan data hasil observasi maka refleksi ini disimpulkan bahawa indikator keberhasilan penelitian $75 \%$ untuk minat siswa belum tercapai, hal ini menurut peneliti masih sangat perlu adanya upaya peningkatan penguatan motivasi dan bimbingan dalam proses pembelajaran baik dalam hal mengerjakan LKS, saling tutorial, saling bantu dengan anggota, saling bertanya, mengikuti diskusi, maupun dalam menjawab kuis, karena dilihat dari hasil observasi walaupun sudah banyak peningkatan tetapi hasilnya belum sesuai dengan yang diharapkan.

\section{Berdasarkan}

catatan

/rekomendasi kolabolator:

1. Agar peneliti menginformasikan tujuan pembelajaran/ kompetensi yang ingin dicapai secara rinci sehingga siswa kurang memahami sepenuhnya tentang tugas yang harus dilakukan

2. Agar peneliti memberikan kepercayaan sepenuhnya kepada siswa agar siswa terbiasa berani mengemukakan ide/ 
pendapat, sehingga siswa lebih percaya diri dalam kelompoknya untuk saling tutorial, saling bertanya, dan saling mengikuti diskusi dengan baik, serta dapat menjawab kuis secara mandiri dengan tetap berkompetisi antar kelompok.

3. Agar peneliti meningkatkan motivasi supaya siswa memusatkan perhatian terhadap materi pelajaran, mengerjakan tugas dengan baik, mencatat materi pelajaran, dan memberikan respon positif dalam proses pembelajaran sehingga siswa dapat meningkatkan minat untuk mengerjakan tugas kelompok maupun tugas individu secara maksimal.

4. Dalam pembelajaran yang menerapkan model STAD sudah menunjukkan hasil yang baik ternyata bisa mengaktifkan siswa dan menimbulkan kompetisi yang sehat antar kelompok, maupun antar individu, namun masih perlu dioptimalkan lagi.

Adapun peningkatan minat dalam pembelajaran PKn dengan menerapkan model STAD kompetisi kelompok antara kondisi awal dengan siklus I dapat dilihat pada tabel berikut:
Tabel 4. Peningkatan minat belajar siswa antara kondisi awal dan siklus I

\begin{tabular}{|c|c|c|c|c|c|c|c|c|}
\hline \multirow{2}{*}{$\begin{array}{l}N \\
\mathrm{O}\end{array}$} & \multirow{2}{*}{ Indikator } & \multirow{2}{*}{$\begin{array}{c}\text { Jml } \\
\text { Siswa }\end{array}$} & \multicolumn{2}{|c|}{$\begin{array}{c}\text { Kondisi } \\
\text { Awal }\end{array}$} & \multicolumn{2}{|c|}{ Siklus I } & \multicolumn{2}{|c|}{$\begin{array}{c}\text { Pening- } \\
\text { katan }\end{array}$} \\
\hline & & & $\begin{array}{l}\text { Fr } \\
\text { ek }\end{array}$ & $\%$ & $\begin{array}{l}\mathrm{Fr} \\
\mathrm{ek}\end{array}$ & $\%$ & $\begin{array}{l}\text { Fr } \\
\text { ek }\end{array}$ & $\%$ \\
\hline 1 & $\begin{array}{l}\text { Memusatk } \\
\text { an } \\
\text { perhatian } \\
\text { terhadap } \\
\text { materi } \\
\text { pelajaran }\end{array}$ & 15 & 3 & 20 & 9 & 60 & 6 & 40 \\
\hline 2 & $\begin{array}{l}\text { Mengerjak } \\
\text { an tugas }\end{array}$ & 15 & 4 & 27 & 10 & 67 & 6 & 40 \\
\hline 3 & $\begin{array}{l}\text { Mencatat } \\
\text { materi } \\
\text { pelajaran }\end{array}$ & 15 & 5 & 33 & 11 & 73 & 6 & 40 \\
\hline 4 & $\begin{array}{l}\text { Merespon } \\
\text { positif } \\
\text { terhadap } \\
\text { pelajaran } \\
\text { PKn } \\
\end{array}$ & 15 & 3 & 20 & 9 & 60 & 6 & 40 \\
\hline & & & & 25 & & 65 & & 40 \\
\hline
\end{tabular}

Rumusan tindak lanjut adalah:

1. Peneliti menginformasikan tujuan/ kompetensi yang akan dicapai secara rinci sehingga siswa memahami tugas yang harus dilakukan.

2. Peneliti memberikan kepercayaan sehingga siswa terbiasa berani mengemukakan ide/ pendapat dan percaya diri untuk saling tutorial, saling bertanya, dan saling mengikuti diskusi dengan baik dalam kelompok, dapat menjawab kuis secara mandiri dengan tetap berkompetisi antar kelompok.

3. Peneliti meningkatkan rangsangan yang lebih kuat supaya siswa termotivasi untuk meningkatkan partisipasi sehingga siswa dapat meningkatkan minat untuk mengerjakan tugas kelompok maupun tugas individu secara maksimal 
4. Peneliti mengoptimalkan penerapan strategi pembelajaran dengan model STAD kompetisi kelompok, lebih mengaktifkan siswa supaya terjadi kompetisi yang sehat antar kelompok, maupun antar individu.

\section{Siklus II}

\section{Perencanaan}

1. Mengidentifikasi masalah yang ada pada siklus I.

2. Memperbaiki strategi pembelajaran dengan mengoptimalkan penerapan model STAD kompetisi kelompok berdasarkan hasil refleksi siklus I.

3. Menyusun Rencana Pelaksanaan Pembelajaran untuk siklus II sesuai hasil refleksi siklus I dengan memperbaiki strategi.

4. Memfokuskan tujuan pembelajaran yang sama dengan siklus I. Guru juga memberikan penguatan/ motivasi agar siswa mengikuti semua pelajaran dengan sepenuh hati dan menanamkan pemahaman bahwa semua pelajaran itu penting baik yang di-UN-kan maupun tidak di-UN-kan. Diiformasikan pula tentang kegiatan pertemuan yang akan datang.

\section{Hasil Tindakan}

1. Hasil pengamatan terhadap proses pelaksanaan tindakan dapat dilihat pada tabel berikut:
Tabel 5. Proses Pelaksanaan STAD Kuis Kompetisi Siklus II

\begin{tabular}{|c|c|c|c|c|}
\hline $\begin{array}{l}\mathrm{N} \\
\mathrm{o}\end{array}$ & Indikator & $\begin{array}{l}\text { Juml } \\
\text { Siswa }\end{array}$ & Frek & $\begin{array}{c}\text { Prosenta } \\
\text { se } \\
(\%) \\
\end{array}$ \\
\hline \multirow[t]{6}{*}{1} & $\begin{array}{l}\text { Kemauan siswa untuk } \\
\text { mengerjakan LKS }\end{array}$ & \multirow{6}{*}{15} & & \\
\hline & $\begin{array}{ll}\text { a. Siswa selalu } \\
\text { mengerjakan LKS }\end{array}$ & & 10 & 66,67 \\
\hline & $\begin{array}{ll}\text { b. } & \begin{array}{l}\text { Siswa sering } \\
\text { mengerjakan LKS }\end{array}\end{array}$ & & 5 & 33,33 \\
\hline & $\begin{array}{ll}\text { c. } & \text { Siswa jarang } \\
& \text { mengerjakan LKS }\end{array}$ & & - & - \\
\hline & $\begin{array}{ll}\text { e. } & \begin{array}{l}\text { Siswa tidak pernah } \\
\text { mengerjakan LKS }\end{array}\end{array}$ & & - & - \\
\hline & Total & & 15 & 100 \\
\hline 2 & $\begin{array}{l}\text { Kemauan siswa untuk } \\
\text { saling tutorial } \\
\text { a. Siswa selalu saling } \\
\text { tutorial }\end{array}$ & \multirow{5}{*}{15} & 3 & 20 \\
\hline & $\begin{array}{l}\text { b. Siswa sering saling } \\
\text { tutorial }\end{array}$ & & 10 & 66,67 \\
\hline & $\begin{array}{l}\text { c. Siswa jarang sering } \\
\text { tutorial }\end{array}$ & & 2 & 13,33 \\
\hline & $\begin{array}{l}\text { d. Siswa tidak pernah } \\
\text { saling tutorial }\end{array}$ & & - & - \\
\hline & Total & & 15 & 100 \\
\hline 3 & $\begin{array}{l}\text { Kemauan siswa untuk } \\
\text { saling bantu anggota } \\
\text { a. Siswa selalu saling } \\
\text { bantu anggota }\end{array}$ & \multirow{5}{*}{15} & 3 & 20 \\
\hline & $\begin{array}{l}\text { b. Siswa sering saling } \\
\text { bantu }\end{array}$ & & 12 & 80 \\
\hline & $\begin{array}{l}\text { c. Siswa jarang saling } \\
\text { bantu anggota }\end{array}$ & & - & - \\
\hline & $\begin{array}{l}\text { d. Siswa tidak pernah } \\
\text { saling bantu anggota }\end{array}$ & & - & - \\
\hline & Total & & 15 & 100 \\
\hline \multirow[t]{5}{*}{4} & $\begin{array}{l}\text { Kemauan siswa untuk } \\
\text { saling bertanya } \\
\text { a. Siswa selalu saling } \\
\text { bertanya }\end{array}$ & \multirow{5}{*}{15} & 3 & 20 \\
\hline & $\begin{array}{l}\text { b. Siswa sering saling } \\
\text { bertanya }\end{array}$ & & 11 & 73,33 \\
\hline & $\begin{array}{l}\text { c. Siswa jarang saling } \\
\text { bertanya }\end{array}$ & & 1 & 6,67 \\
\hline & $\begin{array}{l}\text { d. Siswa tidak pernah } \\
\text { saling bertanya }\end{array}$ & & - & - \\
\hline & Total & & 15 & 100 \\
\hline 5 & $\begin{array}{l}\text { Kemauan siswa untuk } \\
\text { mengikuti diskusi } \\
\text { a. Siswa selalu mengikuti } \\
\text { diskusi }\end{array}$ & \multirow{5}{*}{15} & 4 & 26,67 \\
\hline & $\begin{array}{l}\text { b. Siswa sering mengikuti } \\
\text { diskusi }\end{array}$ & & 9 & 60 \\
\hline & $\begin{array}{l}\text { c. Siswa jarang mengikuti } \\
\text { diskusi }\end{array}$ & & 2 & 13,33 \\
\hline & $\begin{array}{l}\text { d. Siswa tidak pernah } \\
\text { mengikuti diskusi }\end{array}$ & & - & - \\
\hline & Total & & 15 & \\
\hline \multirow[t]{5}{*}{6} & $\begin{array}{l}\text { Kemauan siswa } \\
\text { menjawab kuis } \\
\text { a. Siswa selalu menjawab } \\
\text { kuis }\end{array}$ & \multirow{5}{*}{15} & 8 & 53,33 \\
\hline & $\begin{array}{l}\text { b. Siswa sering menjawab } \\
\text { kuis }\end{array}$ & & 7 & 46,67 \\
\hline & $\begin{array}{l}\text { c. Siswa jarang menjawab } \\
\text { kuis }\end{array}$ & & - & - \\
\hline & $\begin{array}{l}\text { d. Siswa tidak pernah } \\
\text { menjawab kuis }\end{array}$ & & - & - \\
\hline & Total & & 15 & 100 \\
\hline
\end{tabular}


Berdasarkan data tersebut dapat dilihat analisis pada tabel berikut:

Tabel 6. Analisis data peningkatan minat siswa pada siklus II

\begin{tabular}{|c|c|c|c|c|c|c|c|}
\hline $\begin{array}{l}\mathrm{N} \\
\mathrm{O}\end{array}$ & $\begin{array}{c}\text { Indikat } \\
\text { or }\end{array}$ & $\begin{array}{c}\text { Jml } \\
\text { sisw } \\
\text { a }\end{array}$ & Ya & $\%$ & $\begin{array}{c}\text { Tida } \\
\mathrm{k}\end{array}$ & $\%$ & $\begin{array}{l}\text { Indikat } \\
\text { or } \\
\text { Perlu } \\
\text { perhat } \\
\text { ian }\end{array}$ \\
\hline 1 & $\begin{array}{l}\text { Memu } \\
\text { satkan } \\
\text { perhat } \\
\text { ian } \\
\text { terhad } \\
\text { ap } \\
\text { materi } \\
\text { pelajar } \\
\text { an }\end{array}$ & 15 & 14 & 93 & 1 & 7 & $\begin{array}{l}\text { Tidak } \\
\text { perlu }\end{array}$ \\
\hline 2 & $\begin{array}{l}\text { Menge } \\
\text { rjakan } \\
\text { tugas }\end{array}$ & 15 & 13 & 87 & 2 & 13 & $\begin{array}{l}\text { Tidak } \\
\text { perlu }\end{array}$ \\
\hline 3 & $\begin{array}{l}\text { Menca } \\
\text { tat } \\
\text { materi } \\
\text { pelajar } \\
\text { an }\end{array}$ & 15 & 14 & 93 & 1 & 7 & $\begin{array}{l}\text { Tidak } \\
\text { perlu }\end{array}$ \\
\hline 4 & $\begin{array}{l}\text { Meres } \\
\text { pon } \\
\text { positif } \\
\text { terhad } \\
\text { ap } \\
\text { pelajar } \\
\text { an PKn }\end{array}$ & 15 & 14 & 93 & 1 & 7 & $\begin{array}{l}\text { Tidak } \\
\text { perlu }\end{array}$ \\
\hline & $\begin{array}{l}\text { Jumlah } \\
\text { rata- } \\
\text { rata(\% } \\
\text { ) }\end{array}$ & & & 91,5 & & 8,5 & \\
\hline
\end{tabular}

Jika dibandingkan dengan siklus I maka pada sklus II minat siswa sudah meningkat di atas dengan yang ditargetkan. Peningkatan tersebut dapat dilihat pada diagram berikut:

Diagram 2. Peningkatan minat siswa dalam pembelajaran $\mathrm{PKn}$

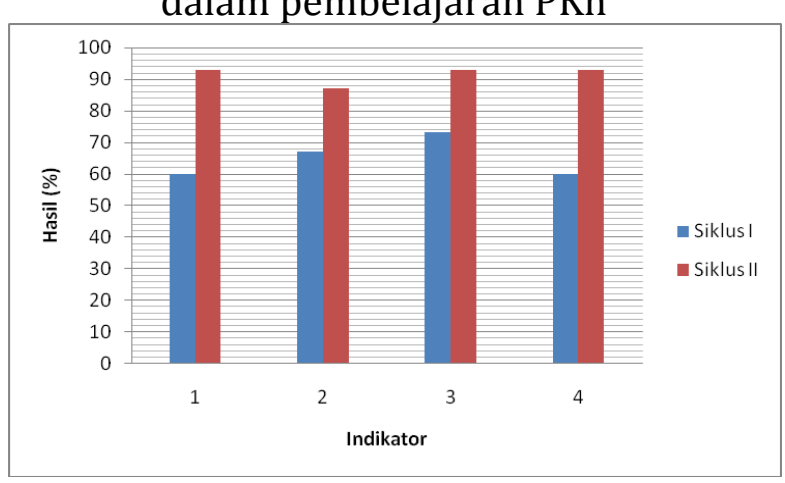

\section{Refleksi}

1. Peneliti sudah menginformasikan tujuan pembelajaran/ kompetensi yang ingin dicapai secara rinci sehingga siswa mampu memahami sepenuhnya tugas yang diberikan.

2. Peneliti sudah memberikan kepercayaan sepenuhnya kepada siswa supaya siswa terbiasa berani mengemukakan ide/ pendapat, sehingga siswa percaya diri untuk mengerjakan LKS, saling tutorial, saling bantu, saling bertanya, dan saling mengikuti diskusi dalam kelompoknya dengan baik, serta dapat menjawab kuis secara mandiri dengan tetap berkompetisi antar kelompok.

3. Peneliti sudah meningkatkan rangsangan yang lebih kuat sehingga siswa termotivasi meningkatkan aktivitas/ partisipasi dalam proses pembelajaran. Hal itu terlihat pada peningkat minat untuk mengerjakan tugas kelompok maupun tugas individu secara maksimal.

4. Model STAD sudah diterapkan secara maksimal sehingga berhasil memotivasi siswa untuk lebih mengaktifkan siswa dan menimbulkan kompetisi yang sehat antar kelompok, maupun antar individu. 
Peningkatan minat siswa dengan menerapkan model STAD kompetisi kelompok pada siklus I dan Siklus II dapat dilihat pada tabel berikut:

Tabel 7. Peningkatan minat belajar siswa antara kondisi siklus I dan siklus II

\begin{tabular}{|c|c|c|c|c|c|c|c|c|}
\hline \multirow[t]{2}{*}{$\begin{array}{l}\mathrm{N} \\
\mathrm{O}\end{array}$} & \multirow[t]{2}{*}{ Idikator } & \multirow[t]{2}{*}{$\begin{array}{c}\text { Jml } \\
\text { Siwa }\end{array}$} & \multicolumn{2}{|c|}{ Siklus I } & \multicolumn{2}{|c|}{ Sklus II } & \multicolumn{2}{|c|}{$\begin{array}{c}\text { Peningkata } \\
\mathrm{n}\end{array}$} \\
\hline & & & $\begin{array}{l}\text { Fr } \\
\text { ek }\end{array}$ & $\%$ & $\begin{array}{l}\text { Fr } \\
\text { ek }\end{array}$ & $\%$ & $\begin{array}{l}\text { Fr } \\
\text { ek }\end{array}$ & $\%$ \\
\hline 1 & $\begin{array}{l}\text { Memusat } \\
\text { kan } \\
\text { perhatia } \\
\text { n } \\
\text { terhadap } \\
\text { materi } \\
\text { pelajara } \\
\text { n }\end{array}$ & 15 & 9 & 60 & 14 & 93 & 5 & 33 \\
\hline 2 & $\begin{array}{l}\text { Mengerj } \\
\text { akan } \\
\text { tugas }\end{array}$ & 15 & 10 & 67 & 13 & 87 & 3 & 20 \\
\hline 3 & $\begin{array}{l}\text { Mencatat } \\
\text { materi } \\
\text { pelajara } \\
\mathrm{n}\end{array}$ & 15 & 11 & 73 & 14 & 93 & 3 & 20 \\
\hline 4 & $\begin{array}{l}\text { Merespo } \\
\mathrm{n} \text { positif } \\
\text { terhadap } \\
\text { pelajara } \\
\mathrm{n} \text { PKn }\end{array}$ & 15 & 9 & 60 & 14 & 93 & 5 & 40 \\
\hline & $\begin{array}{l}\text { Rerata } \\
\text { prosenta } \\
\text { se } \\
\text { ketercap } \\
\text { aian } \\
\end{array}$ & & & 65 & & $\begin{array}{r}91 \\
, 5\end{array}$ & & \\
\hline
\end{tabular}

Data dari tabel tersebut dapat diinterpretasikan bahwa indikator semua aspek minat pada siklus I dan siklus II mengalami peningkatan sesuai harapan. Rerata prosentase ketercapaian meningkat dari 65\% menjadi 91,5\%.

Dengan memperhatikan data hasil tindakan sampai dengan siklus II, baik dari segi proses pelaksanaan tindakan maupun peningkatan minat, dapat dikatakan semua sudah mencapai kriteria keberhasilan tindakan oleh karena itu tidak perlu dilakukan siklus berikutnya. Ada seorang siswa yang masih belum sepenuhnya bisa memusatkan perhatian, mencatat materi, dan merespon positif terhadap PKn, serta terdapat dua orang siswa yang mengerjakan tugas belum secara keseluruhan. Terhadap siswa-siswa tersebut perlu diberikan bimbingan khusus melalui pendekatan personal.

Dari proses penelitian tindakan kelas terdapat beberapa hal yang dapat dianalisis. Menurut Rogers, yang dikutip Rumini, dkk (1995: 108), manusia mempunyai hasrat alami untuk belajar. Hal ini mudah dibuktikan: perhatikan saja betapa ingin tahunya anak kalau sedang mengekplorasi lingkungannya. Dorongan ingin tahu untuk belajar ini merupakan asumsi dasar pendidikan humanistik. Di dalam kelas yang humanistik anak-anak diberi kesempatan dan kebebasan untuk memuaskan dorongan ingin tahunya, untuk memenuhi minatnya dan untuk menemukan apa yang penting dan berarti tentang dunia di sekitarnya.

Berdasarkan uraian tersebut minat belajar sangat menentukan keberhasilan dalam pembelajaran. Hasrat untuk belajar sehingga dapat menemukan sesuatu yang penting dalam kehidupan dan bermakna tentang dunia di sekitarnya. Untuk itu minat/ hasrat dapat timbul karena adanya kebutuhan. Siswa perlu diberi motivasi, didorong, diberikan penguatan suapaya menyadari bahwa 
pedidikan kewarganegaraan itu merupakan salah satu kebutuhan yang harus terpenuhi bagi setiap warga negara. Dalam kegiatan pembelajaran PKn perlu adanya rangsangan yang dapat meningkatkan minat belajar.

Menurut Endang dan Made (2010:

87) beberapa strategi yang dapat merangsang minat dan perhatian peserta didik adalah:a) menggunakan metode yang bervariasi b) menggunakan media c) menggunakan humor d) menggunakan fakta/ peristiwa nyata, juga dapat menunjang dan memperjelas konsep yang disampaikan. Sejalan dengan uraian tersebut lebih jebih memperjelas bahwa ada berbagai upaya yang dapat dilakukan oleh guru, selain menggunakan strategi, pendekatan maupun model pembelajaran juga memanfaatkan media yang sesuai dengan tujuan dan materi pembelajaran. Agar tujuan pembelajaran PKn tercapai maka harus bisa meningkatkan minat siswa dalam kegiatan pembejaran selain memanfaatkan media/ alat yang ada, menggunakan metode bervariasi juga menerapkan model pembelajaran. Berbagai strategi maupun model pembelajaran yang bisa digunakan untuk menyiasati agar bisa meningkatkan minat siswa, di antaranya model pembelajaran STAD kuis kompetisi kelompok.
Berdasarkan uraian tersebut di atas, dengan menerapkan model pembelajaran STAD kuis kompetisi kelompok dapat meningkatkan minat belajar PKn yang pada akhirnya akan berdampak positif terhadap hasil belajar.

\section{Penerapan Model Pembelajaran}

\section{Kooperatif Student Team Achiement}

Divitions (STAD) Kuis Kompetisi Kelompok dalam Meningkatkan Minat Belajar PKn

Peningkatan minat belajar dapat dilihat dari hasil observasi langsung dalam proses pembelajaran melalui penerapan teknik STAD kuis kompetisi kelompok pada siklus I dan siklus II. Penerapan model pembalajaran STAD ini untuk meningkatkan minat belajar PKn dengan memperbaiki proses pembelajaran yang selama ini guru masih mendominasi. Setiap pembelajaran dalam STAD dimulai dengan presentasi pelajaran yang mencakup pembukaan, pengembangan, dan pengarahan praktis tiap komponen dari keseluruhan; kegiatan-kegiatan tim dan kuis yang meliputi latihan dan penilaian.

Untuk menumbuhkan rasa ingin tahu dan minat belajar siswa, maka pada bagian pembukaan (bagian pendahuluan) disampaikan kepada siswa tentang apa dan pentingnya materi Sistem politik di 
Indonesia yang harus mereka pelajari, dikaitkan dengan masalah dalam kehidupan nyata. Di samping itu para siswa bekerja dalam tim diberi motivasi untuk menemukan konsep-konsep untuk membangkitkan minat mereka terhadap materi pelajaran.

Dalam pengembangannya terfokus pada materi Sistem politik di Indonesia yang ingin dipelajari pada pemaknaan bukan penghapalan, mendemonstrasikan konsep-konsep dengan menggunakan alat bantu visual, dan menilai siswa sesering mungkin dengan memberi banyak pertanyaan. Siswa dirangsang agar selalu mengerjakan tiap soal, dan mempersiapkan jawaban pertanyaan.

Selama belajar dalam tim, para anggota bertugas menguasai materi dan membantu teman sekelasnya untuk menguasai materi tersebut. Para siswa mempunyai lembar kegiatan dan lembar jawaban yang dapat digunakan untuk melatih kemampuan selama proses pembelajaran. Pada waktu siswa mengerjakan kuis secara individual, tidak boleh saling bantu. Siswa saling bertukar lembar jawaban kuis ataupun mengumpulkan kuis untuk dinilai setelah pembelajaran selesai.

Menurut Slavin (2009:159) jika memungkinkan umumkanlah skor tim pada periode pertama setelah mengerjakan kuis. Ini akan membuat jelas hubungan antara melakukan tugas dengan baik dan menerima rekognisi, pada akhirnya akan meningkatkan motivasi mereka untuk melakukan yang terbaik. Sejalan dengan hal tersebut, maka sesegera mungkin setelah melakukan tiap kuis dilakukan pengenghitungan skor tim maupun skor individu, kemudian memberi penghargaan kepada tim dengan skor tertinggi.

STAD kuis kompetisi kelompok menekankan pada aktivitas siswa dalam hal mengerjakan LKS, saling tutorial, saling bantu, saling bertanya, mengikuti diskusi, dan menjawab kuis. Dengan menerapkan teknik STAD ini diharapkan dapat meningkatkan minat belajar pada pembelajaran PKn. Keberhasilan proses pembelajaran dalam penelitian tindakan ini ditunjukkan dengan meningkatnya minat belajar PKn yang mencakup aspek pemusatan perhatian terhadap materi pelajaran, mengerjakan tugas, mencatat materi pelajaran, dan respon positif terhadap pelajaran PKn dapat dilihat pada hasil penelitian di atas. Untuk mengetahui perbandingan minat belajar siswa dapat dilihat pada prosentase peningkatan setiap indikator dan prosentase rerata peningkatan minat yang dicapai dari hasil tindakan siklus I dan siklus II. 
Pada siklus I, skor rerata peningkatan minat dari kondisi awal $25 \%$ menjadi 65\%, sehingga mengalami peningkatan $40 \%$. Walaupun minat belajar tersebut sudah menunjukkan peningkatan dari kondisi awal tetapi belum sesuai dengan target yang ingin dicapai. Kemudian pada siklus II dilakukan perbaikan tindakan untuk meningkatkan minat belajar agar sesuai target yang diharapkan. Hasil yang dicapai dari tindakan pada siklus II menunjukkan skor rerata minat belajar 91,5\%. Dengan demikian, minat belajar pada siklus II sudah mencapai target sesuai yang diharapkan pada penelitian ini yaitu $75 \%$ maka tidak perlu dilakukan siklus selanjutnya.

Peningkatan minat belajar siswa tersebut seiring dengan peningkatan aktivitas dan partisipasi siswa dalam proses pembelajaran STAD kuis kompetisi kelompok dari siklus I dan siklus II. Dilihat dari indikator setiap aspek menunjukkan bahwa seluruh siswa mengalami peningkatan dalam hal mengerjakan LKS, saling tutorial, saling bantu anggota, saling bertanya, dan dalam menjawab kuis.

Adapun peningkatan minat siswa mulai dari kondisi awal, siklus I, dan siklus II dalam pembelajaran PKn dapat dilihat pada diagram di bawah ini.
Diagram 3. Peningkatan minat siswa dari kondisi Awal, Siklus I, dan Siklus II

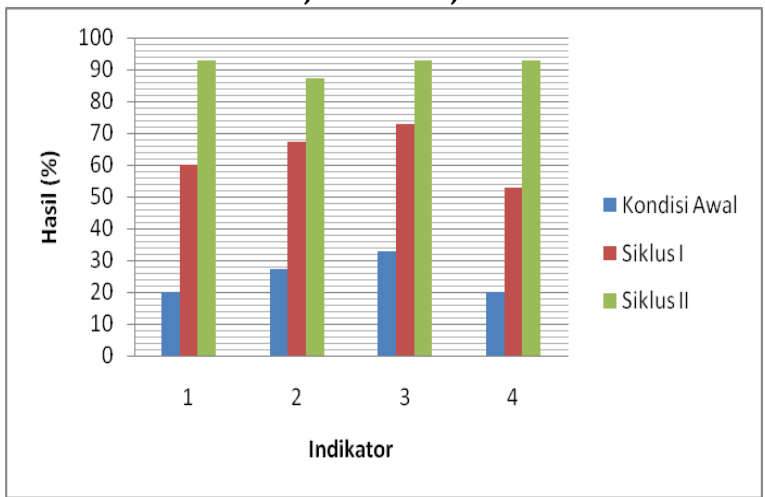

Peningkatan minat siswa dalam belajar PKn dengan menggunakan model Pembelajaran STAD kuis kompetisi kelompok terlihat jelas dalam diagram tersebut. Adanya peningkatan minat tersebut karena kegiatan pembelajaran mampu menarik perhatian, sehingga siswa mampu memusatkan perhatian, mengerjakan tugas dengan baik, mencatat materi, dan merespon positif terhadap pelajaran. Di samping itu siswa juga berminat untuk mengerjakan LKS, saling tutorial, saling Bantu, saling bertanya, aktif mengikuti diskusi, dan menjawab kuis dengan baik

\section{SIMPULAN}

Diperoleh bukti secara empiris ternyata model pembelajaran STAD kuis kompetisi kelompok dapat meningkatkan minat belajar siswa pada mata pelajaran PKn. Hal tersebut terlihat pada hasil analisis data pengamatan rerata peningkatan minat belajar siswa dari kondisi awal $25 \%$ meningkat pada siklus I menjadi 
$65 \%$, kemudian pada siklus II meningkat menjadi 91,5\%.

Agar Pembelajaran PKn dapat menarik minat siswa, maka dalam penelitian ini diterpkan model pembelajaran STAD yang dilakukan dengan cara: (1) Pada tahap pendahuluan guru harus memulai dengan presentasi pelajaran yang mencakup pembukaan,pengembangan, dan pengarahan praktis tiap komponen dari keseluruhan; (2) Pada kegiatan inti guru harus memberi motivasi dan memfasilitasi siswa agar berpartisipasi aktif dalam timnya untuk menguasai materi dengan saling tutorial,saling diskusi,saling bertanya jawab,dan saling bantu. Proses pembelajaran diakhiri dengan mengerjakan kuis secara individual dan tidak boleh saling bantu; (3) Penilaian kuis dilakukan setelah pembelajaran selesai, skor individu juga diperhitungkan untuk skor tim, kemudian kepada tim dengan skor tertinggi diberi penghargaan.

Secara keseluruhan penerapan model pembelajaran STAD kuis kompetisi kelompok secara maksimal dapat meningkatkan minat belajar PKn pada siswa kelas X ATU 2 di SMK Negeri 1 Pandak tahun pelajaran 2013/2014.

\section{UCAPAN TERIMA KASIH}

Penulis mengucapkan terima kasih kepada civitas akademik di SMK N 1 Pandak yang telah membantu proses penelitian. Selain itu kepada MGMP PKn Kabupaten Bantul yang selalu memberikan dukungan terhadap peningkatan kompetensi guruguru PKn di Kabupaten Bantul. Selanjutnya kami ucapkan terima kasih kepada redaksi yang telah mempublikasikan artikel hasil penelitian ini sehingga penelitian ini dapat dibaca oleh berbagai kalangan. Hasil penelitian ini masih dapat dikembangkan ke dalam bentuk penelitian lain sehingga kami berharap penelitian ini dapat dijadikan sebagai referensi terhadap penelitian selanjutnya. Semoga hasil penelitian ini bermanfaat bagi perkembangan ilmu pengetahuan. Harapan lain semoga guruguru semakin semangat membuat karya penelitian.

\section{DAFTAR PUSTAKA}

Boediono. 1998. Panduan Manajemen Sekolah. Jakarta. Depdikbud.

Departemen Pendidikan Nasional. 2006. Peraturan Menteri Pendidikan Nasional Republik Indonesia Nomor 22 Tahun 2006 tentang Standar Isi untuk Satuan Pendidikan Dasar dan Menengah. Jakarta: Depdiknas. 
Rahayu, Endang Sadbudhy dan I Made Nuryata. 2010. Pembelajaran Masa Kini. Jakarta: Sekarmita Training and Publishing.

Rumini, Sri. 1995. Psikologi Pendidikan. Yogyakarta : FIP UNY.

Sagala, Syaiful. 2004. Konsep dan Makna Pembelajaran. Bandung: Penerbit Alfabeta.

Slavin, Robert E.. 2009. Cooperative Learning Teori, Riset dan Praktik. Bandung: Penerbit Nusa Media.

Sutikno, M. Sobry. 2007. Menggagas Pembelajaran Efektif dan Bermakna. Mataram : NTP Press.

Tukiran Taniredja. 2013. Konsep Dasar Pendidikan Kewarganegaraan. Yogyakarta: Penerbit Ombak. 